\title{
The influence of habitat on metabolic and digestive parameters in an intertidal crab from a SW Atlantic coastal lagoon
}

\author{
Eugenia Méndez, M. Soledad Michiels \& Alejandra A. López-Mañanes * \\ Instituto de Investigaciones Marinas y Costeras (IIMyC), Consejo Nacional de Investigaciones \\ Científicas y Técnicas (CONICET) - Universidad Nacional de Mar del Plata, \\ Funes 3250 (7600) Mar del Plata, Argentina. \\ *Corresponding author: mananes@mdp.edu.ar
}

\begin{abstract}
The hepatopancreas of decapod crustaceans is an organ which can act as indicator for digestive and metabolic parameters under different physiological and/or environmental conditions. However, biochemical studies on digestive and metabolic parameters of the hepatopancreas of euryhaline burrowing crabs such as Neohelice granulata from habitats with different diet compositions are still scarce. In the wild, adult males of $N$. granulata from Mar Chiquita Coastal Lagoon (Argentina) in mudflat habitat have diets with higher lipid and protein content than crabs from the saltmarsh, suggesting that diets could be an important factor influencing hepatopancreas activities. We tested this hypothesis here by exposing adult male crabs to a similar experimental diet and comparing hepatopancreas parameters for lipid components and protein metabolism between males from these two habitat types at different times (up to three months). At month 3, we noticed a decrease of the triglyceride concentration and lipase activity and an increase of protein concentration in crabs from the mudflat. In contrast, triglycerides and protein concentration did not change in crabs from the saltmarsh, while lipase activity decreased and levamisole insensitive AP increased at month 3. The results indicate that digestive and metabolic parameters in the hepatopancreas of crabs from habitats varying in diet content remain different, even if crabs are subsequently fed by a similar experimental diet. This suggests that specific intrinsic regulations of these hepatopancreas parameters could operate differently in each habitat and could not be changed by recent diet conditions.
\end{abstract}

Keywords. Intertidal crabs, hepatopancreas, energy reserves, lipase, alkaline phosphatase.

MÉNDEZ E., Michiels M.S. \& LÓPEZ-MAÑANES A.A. (2021). The influence of habitat on metabolic and digestive parameters in an intertidal crab from a SW Atlantic coastal lagoon. Belgian Journal of Zoology 151: 81-98. https://doi.org/10.26496/bjz.2021.87

\section{Introduction}

The hepatopancreas of decapod crustaceans is a sensitive indicator organ for digestive and metabolic adjustments to distinct physiological and/or environmental conditions (BELGRAD \& GRIFFEN 2016; PINONI et al. 2018; LÓPEZ MAÑANES et al. 2020). In various intertidal burrowing crabs, the modulation of specific digestive enzymes and/or energy reserves in the hepatopancreas is part of the responses involved in biochemical adaptation to key environmental challenges such as salinity and food availability 
(MiCHIELS et al. 2017; PINONI et al. 2018; LÓPEZ MAÑANES et al. 2020). In intertidal crabs of the same species successfully inhabiting different habitats in a same intertidal area (e.g., mudflat or saltmarsh) of coastal lagoons, the distinct and particular environmental conditions in each habitat may impose distinct challenges leading to intraspecific differences in responses, for example, at the biochemical level (PINONI et al. 2011; MUELler 2017; LÓPEZ MAÑANES et al. 2020). This could imply the presence of different intrinsic regulatory mechanisms in crabs coming from different habitats that persist even when they are subsequently exposed to the same laboratory conditions (PINONI et al. 2013; LÓPEZ MAÑANES et al. 2020). This could indeed be the case for adult males of Neohelice granulata from mudflat and saltmarsh habitats of Mar Chiquita Coastal Lagoon (Buenos Aires Province, Argentina) which show intraspecific differences in lipid and protein metabolism components in the hepatopancreas under exposure to identical osmotic conditions (PINONI et al. 2013; LÓPEZ MAÑANES et al. 2020), but there are currently no other studies of this kind on the influence of key environmental parameters on the biochemistry of metabolic and digestive adjustments in intertidal crabs.

Neohelice granulata (Dana, 1851) (phylum Arthropoda, subphylum Crustacea, class Malacostraca) is a euryhaline burrowing crab that is found in intertidal areas of the southwestern Atlantic from southern Brazil to northern Argentinean Patagonia where it plays a key ecological role (LUPPI et al. 2013; ANGELETTI \& CERVELLINI 2015; SPIVAK 2020). The same population of this crab can inhabit different habitats such as mudflats or saltmarshes (LUPPI et al. 2013; NUÑEZ et al. 2020). The modulation of key enzymes in the hepatopancreas such as lipase or levamisole-insensitive and -sensitive alkaline phosphatase (AP) is one of the possible responses at the biochemical level to external and internal factors in $N$. granulata (PINONI 2009; PINONI et al. 2015; Michiels et al. 2015a; LÓPEZ MAÑANES et al. 2020). In Mar Chiquita Coastal Lagoon, adult males of $N$. granulata occupy both the mudflat and the saltmarsh habitats (LUPPI et al. 2013). In the mudflat, $N$. granulata consumes more items of animal origin, thus sustaining a richer diet in lipids and proteins compared to crabs in the saltmarsh. In the saltmarsh, crabs consume more plant items, mainly Spartina densiflora, the main cordgrass in this habitat (PINONI et al. 2011, 2013; LUPPI et al. 2013; LANCIA et al. 2014). In autumn, adult males of $N$. granulata stay for up to 3 months in burrows of both mudflat and saltmarsh, where they feed, which leads to between-habitat differences in digestive and metabolic characteristics (e.g., levels and/or modulation of energy reserves and key enzymes in hepatopancreas) (PINONI et al. 2011; LÓPEZ MAÑANES et al. 2020). Varying triglyceride and protein concentrations in the hepatopancreas are part of biochemical adaptations to each habitat type (PINONI et al. 2011; LÓPEZ MAÑANES et al. 2020). Therefore, adult males of $N$. granulata provide a good model to compare the effect of diet on digestive and metabolic components at the biochemical level between habitats. We propose that diet should differently affect the content of energy reserves and key enzymes in the hepatopancreas of crabs from the mudflat and the saltmarsh, likely due to the particular digestive and metabolic characteristics of crabs in each habitat. (PINONI et al. 2011; LÓPEZ MAÑANES et al. 2020). The aim of our study was to test whether a similar diet under controlled conditions influences key components of lipid and protein metabolism in the hepatopancreas of adult males of crabs from mudflat and the saltmarsh habitats differently. For this purpose, we determined the concentration of triglycerides and protein reserves and lipase and levamisole-sensitive and -insensitive AP activity in the hepatopancreas along with the hepatosomatic index (liver weight as a percentage of the whole body weight) as parameters for physical condition (ALBANESI et al. 2020) in crabs from both the mudflat and the saltmarsh of Mar Chiquita Coastal Lagoon immediately after capture and after one and three months in the lab, respectively.

\section{Material and methods}

\section{Animal collection and maintenance}

Adult male crabs in intermolt $(\mathrm{n}=80)$ (carapace width greater than $2.5 \mathrm{~cm}$ ) were live trapped in autumn (May 2013) from burrows of the open mudflat and saltmarsh habitats of the Argentinian Mar Chiquita 
Coastal Lagoon $\left(37^{\circ} 32^{\prime}-37^{\circ} 45^{\prime} \mathrm{S}, 5^{\circ} 19^{\prime}-57^{\circ} 26^{\prime} \mathrm{W}\right)$ (PINONI et al. 2011, 2013) (Fig. 1). Variations in key environmental conditions such as temperature (T) and salinity (S) are wider in burrows from the mudflat than in the saltmarsh (mudflat: $\Delta \mathrm{T}^{\circ} \mathrm{C} 10.8, \Delta \mathrm{S}: 17.2$; saltmarsh $\Delta: \mathrm{T}^{\circ} \mathrm{C} 5.8, \Delta \mathrm{S}: 10.5$ ) (LuPPI et al. 2013). The chosen sampling time of the crabs and the experimental period are based on the fact that the movement of adult male crabs between the two habitat types is highly reduced during autumn as male crabs remain up to 3 months inside their burrows (LUPPI et al. 2013; personal observations). Captured animals were transported to the laboratory in the water of the collection site under continuous aeration which took about 30 minutes. One group of crabs from both the mudflat and the saltmarsh each was immediately investigated with biochemical assays without any acclimation at time zero $\left(\mathrm{t}_{0}\right)$. Other groups of crabs from each habitat type were maintained in separate aquaria (2 aquaria with 30 individuals per aquarium) under controlled conditions: $35 \mathrm{psu}$; salinity at which adult males from both sites from Mar Chiquita Coastal Lagoon exhibit the same hemolymph osmotic concentration as that of the external medium; therefore they are osmo-conform (PINONI et al. 2013); 12-h light/12-h dark; $20 \pm 2^{\circ} \mathrm{C}$, and $\mathrm{pH}$ 7.4. $36 \mathrm{~L}$ of water were continuously aerated, filtered with Atman filters (HF-0400) and partially changed every second day as previously described (PINONI et al. 2013; Michiels et al.

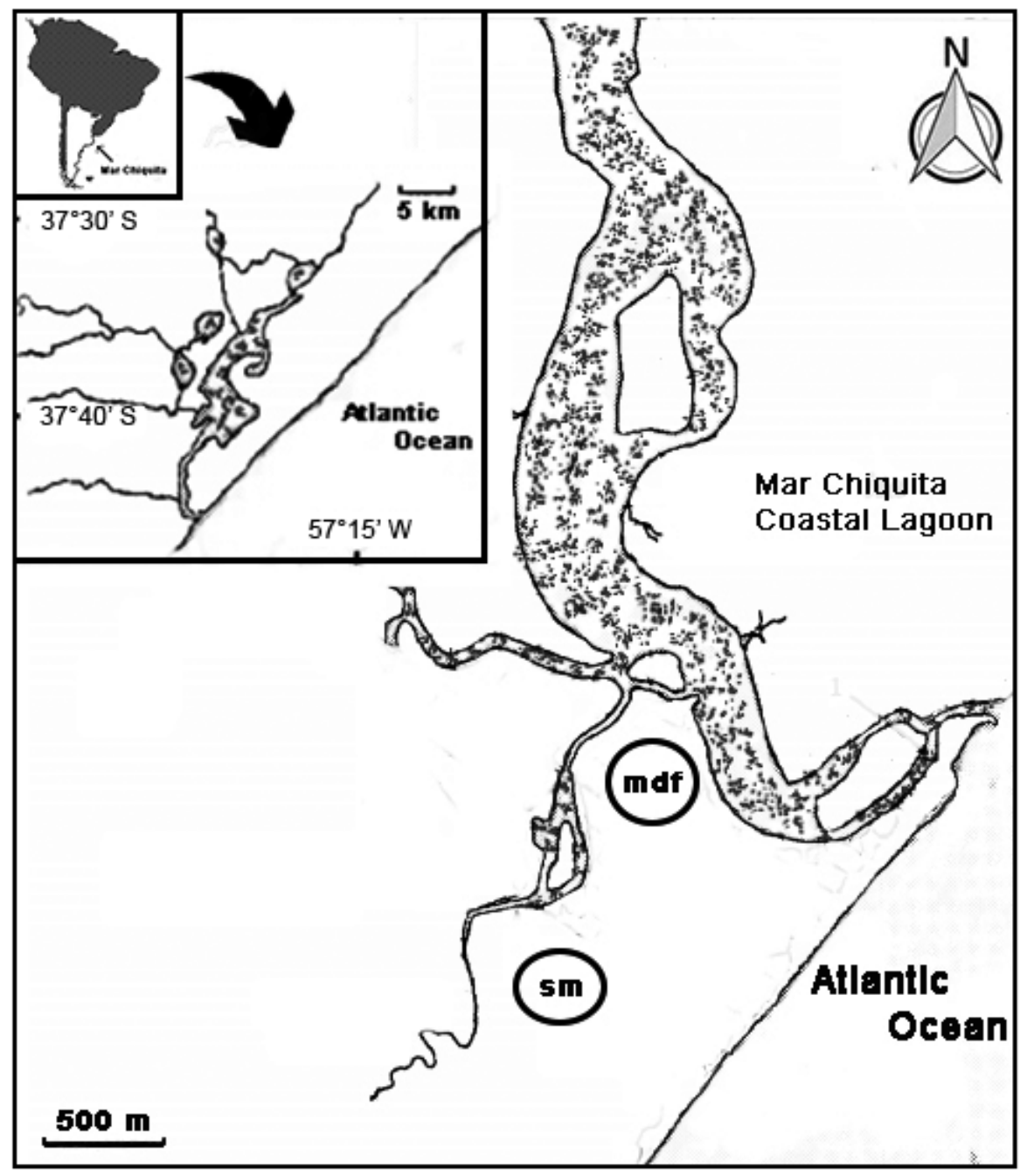

Fig. 1 - Map of the Argentinian Mar Chiquita Coastal Lagoon with exact position of the sampling sites and the two habitat types, mudflat (mdf) and saltmarsh (sm). Inset: geographical position of the Mar Chiquita Coastal Lagoon. 
2015a). Crabs were fed three times a week with commercial fish food from TetraPond (containing $62 \%$ carbohydrates; $31 \%$ proteins; $5 \%$ lipids) throughout the experimental period (up to 3 months); all examined individual were starved $24 \mathrm{~h}$ prior to biochemical assays. At months 1 and 3, triglyceride and protein content and digestive enzymes activities were determined in the hepatopancreas as described below. The feeding behavior was monitored as described by MÉNDEZ et al. (2019) while crabs were individually fed $(0.07 \mathrm{~g})$. Only animals which consumed the total amount of offered food, which took up to 5 min, were used for subsequent analyses (MÉNDEZ et al. 2019).

\section{Preparation of hepatopancreas extracts}

The hepatopancreas extracts were prepared as described in literature (PINONI et al. 2013; MichIELS et al. 2020). Briefly, crabs were weighed and cold-anaesthetized for about $20 \mathrm{~min}$. The hepatopancreas was homogenized in $50 \mathrm{~mm}$ Tris/ $\mathrm{HCl} \mathrm{pH} 7.4\left(4 \mathrm{ml} \mathrm{g}\right.$ tissue $\left.^{-1}\right)$ (CAT homogenizer XI20, tool T10) and centrifuged at $10,000 \mathrm{~g}$ for $15 \mathrm{~min}$ (Sorval, rotor SS34, at $4^{\circ} \mathrm{C}$ ). Before centrifugation, an aliquot of homogenate was removed to determine the triglyceride and protein content. The supernatant was separated into aliquots and glycerol $\left(1.3 \% \mathrm{v} \mathrm{v}^{-1}\right)$ was added before freezing (LJUNGSTRÖM et al. 1984) until the samples were later used for enzymatic assays.

\section{Biochemical assays}

Triglycerides (TG) were measured by the colorimetric method of glycerol phosphate oxidase with a commercial kit (TG Wiener Lab AA cod. 861110001) as described (PINONI et al. 2013; MichIELS et al. 2015b). Each sample was incubated with chlorophenol, lipoprotein lipase (LPL), glycerol kinase (GK), glycerol phosphate oxidase (GPO), peroxidase (POD), adenosine triphosphate (ATP) and 4-aminophenazone (4-AF) in buffer 'Good' ( $\mathrm{pH}$ 6,8) (Reactive A of the kit) for 5 min at $37^{\circ} \mathrm{C}$. The amount of released glycerol was determined by estimating the absorbance of the colored quinonimine complex at $505 \mathrm{~nm}$ (spectrophotometer ZL5000 PLUS, Zeltec).

Protein assays were conducted according to BRADFORD (1976) monitoring the increase in absorption at $595 \mathrm{~nm}$ produced by the binding of the dye Coomasie Brilliant Blue G-50 to proteins (spectrophotometer ZL5000 PLUS, Zeltec). Bovine serum albumin was used as protein concentration standard to build the corresponding standard curve and to calculate the protein concentrations of the samples (PINONI et al. 2013; MiCHIELS et al. 2015a, 2017).

All biochemical parameters were always determined from a single sample that had not been defrosted prior to analyses. Previous work in our laboratory showed that the freezing procedure did not alter the estimated activities as values were stable for at least up to eight months of freezing (MÉNDEZ et al. 2019; LÓPEZ MAÑANES et al 2020). The assay conditions used had been determined as optimal to measure activity in the hepatopancreas of N. granulata (PINONI 2009; MiCHIELS et al. 2015a, 2015b).

Lipase activity was determined by measuring pNP-palmitate hydrolysis (MARKWEG et al. 1995) with some modifications as described by MICHIELS et al. (2015a). The reaction was initiated by adding pNPpalmitate (final concentration $0.7 \mathrm{~mm}$ ) to a reaction mixture containing the corresponding sample in $50 \mathrm{~mm}$ Tris- $\mathrm{HCl}$ buffer $(\mathrm{pH} 8.5) / 4 \mu \mathrm{l}$ of Tween 80 . Incubation was carried out at $37^{\circ} \mathrm{C}$ for $3 \mathrm{~min}$. The reaction was stopped by addition $0.5 \mathrm{ml}$ of $0.2 \% \mathrm{w} \mathrm{v}^{-1}$ of trichloroacetic acid (TCA). The amount of released p-nitrophenol (pNP) was determined by absorbance at $410 \mathrm{~nm}$ (spectrophotometer ZL5000 PLUS, Zeltec).

Levamisole-insensitive and -sensitive alkaline phosphatases (AP) activities were determined as in PINONI et al. (2005) and PINONI \& LÓPEZ MAÑANES (2008). AP (EC 3.1.3.1) are membrane-bound 
MÉNDEZ E. et al., Intraspecific digestive and metabolic variability in an intertidal crab

glycoproteins that are widely found in animals which hydrolyse phosphate from a variety of molecules at a range of optimal $\mathrm{pH}$ above 7.0 (LALLÈS 2019). Levamisole is an inhibitor used to discriminate between different AP isoforms (CHAN \& STINSON 1986; PINONI et al. 2005, 2015; MOTA et al. 2008; DiEZZAERA et al. 2011; LALLÈS 2019). Levamisole-insensitive AP activity was determined by measuring pNPP hydrolysis in a reaction medium containing $4 \mathrm{~mm} \mathrm{MgSO} 4$ in $0.1 \mathrm{M}$ Tris- $\mathrm{HCl}$ buffer (pH 7.7) in the presence of $16 \mathrm{~mm}$ levamisole. Levamisole-sensitive AP activity was determined as the difference between the pNPP hydrolysis in a reaction medium containing $4 \mathrm{mM} \mathrm{MgSO} 4$ in $100 \mathrm{~mm}$ Tris- $\mathrm{HCl}$ buffer ( $\mathrm{pH} \mathrm{8.5)} \mathrm{in} \mathrm{the} \mathrm{absence} \mathrm{(total} \mathrm{AP} \mathrm{activity)} \mathrm{and} \mathrm{in} \mathrm{the} \mathrm{presence} \mathrm{of} 16 \mathrm{~mm}$ levamisole. The reaction was initiated by the addition of pNPP (final concentration $9.5 \mathrm{~mm}$ ) and incubation was carried out at $37^{\circ} \mathrm{C}$ for $30 \mathrm{~min}$. The reaction was stopped by adding $2 \mathrm{~mL}$ of $0.1 \mathrm{M} \mathrm{KOH}$. The amount of released pNP was determined by absorbance at $410 \mathrm{~nm}$ (spectrophotometer ZL5000 PLUS, Zeltec).

\section{Hepatosomatic index determination}

To determine the hepatosomatic index (HSI), each crab and also its hepatopancreas was weighed. The hepatosomatic index $(\mathrm{HSI}, \%)=$ hepatopancreatic weight $/$ (body weight - hepatopancreatic weight $) * 100$ was calculated as in ALBANESI et al. (2020) and DA SILVA VIANNA et al. (2020). This index is commonly used as parameter for the maintenance of physical conditions (ALBANESI et al. 2020; DA SILVA VIANNA et al. 2020; LEÃO et al. 2021).

\section{Statistical analysis}

Statistical analyses were conducted using the Sigma-Stat 4.0 statistical package for Windows, which automatically performs a test for equal variance and normality among sample groups before subsequently doing parametric tests like ANOVA or t-test. If samples do not pass this test, non-parametric tests are used instead. We chose the most suitable statistical analysis depending on the level of comparison for the same biochemical parameter:

a) One Way Repeated Measure ANOVA was used when analysing the same biochemical parameter at different exposure times to experimental diet of crabs from each site, $p<0.05$ was considered to be significant. This allowed us to test the temporal dynamics of each biochemical parameter. The Bonferroni correction was used to reduce the instances of false positives in multiple comparisons;

b) A t-test was used to compare the values of the same biochemical parameter of crabs from different sites (mudflat versus saltmarsh) at the same exposure time to the experimental diet. The t-test is commonly used to compare the means for the same parameter between two groups (ZAR 1999).

\section{Results}

\section{Hepatopancreas triglyceride concentrations}

In crabs from the mudflat, triglyceride concentrations in the hepatopancreas at month 1 were similar to those at $\mathrm{t}_{0}$. After 3 months (Fig. 2A), we noticed a significant decrease compared to $\mathrm{t}_{0}$ (about $60 \%$; $\left(\mathrm{F}_{(8,2)}=40.5, \mathrm{t}=9, \mathrm{p}=0.002\right)$ and month 1 (about 65\%; $\mathrm{F}_{(8,2)}=40.5, \mathrm{t}=13.9, \mathrm{p}<0.001$ ). In crabs from the saltmarsh, triglyceride concentrations did not change throughout the experimental period (Fig. 2B).

At $\mathrm{t}_{0}$ and month 1, triglyceride concentrations in the hepatopancreas of individuals from the saltmarsh were significant lower (about $80 \%, p<0.001$; and $90 \%, p=0.008$, respectively) compared to the corresponding values in crabs from the mudflat. No significant differences were observed between the two habitat types at month 3 (Fig. 2). 


\section{A}
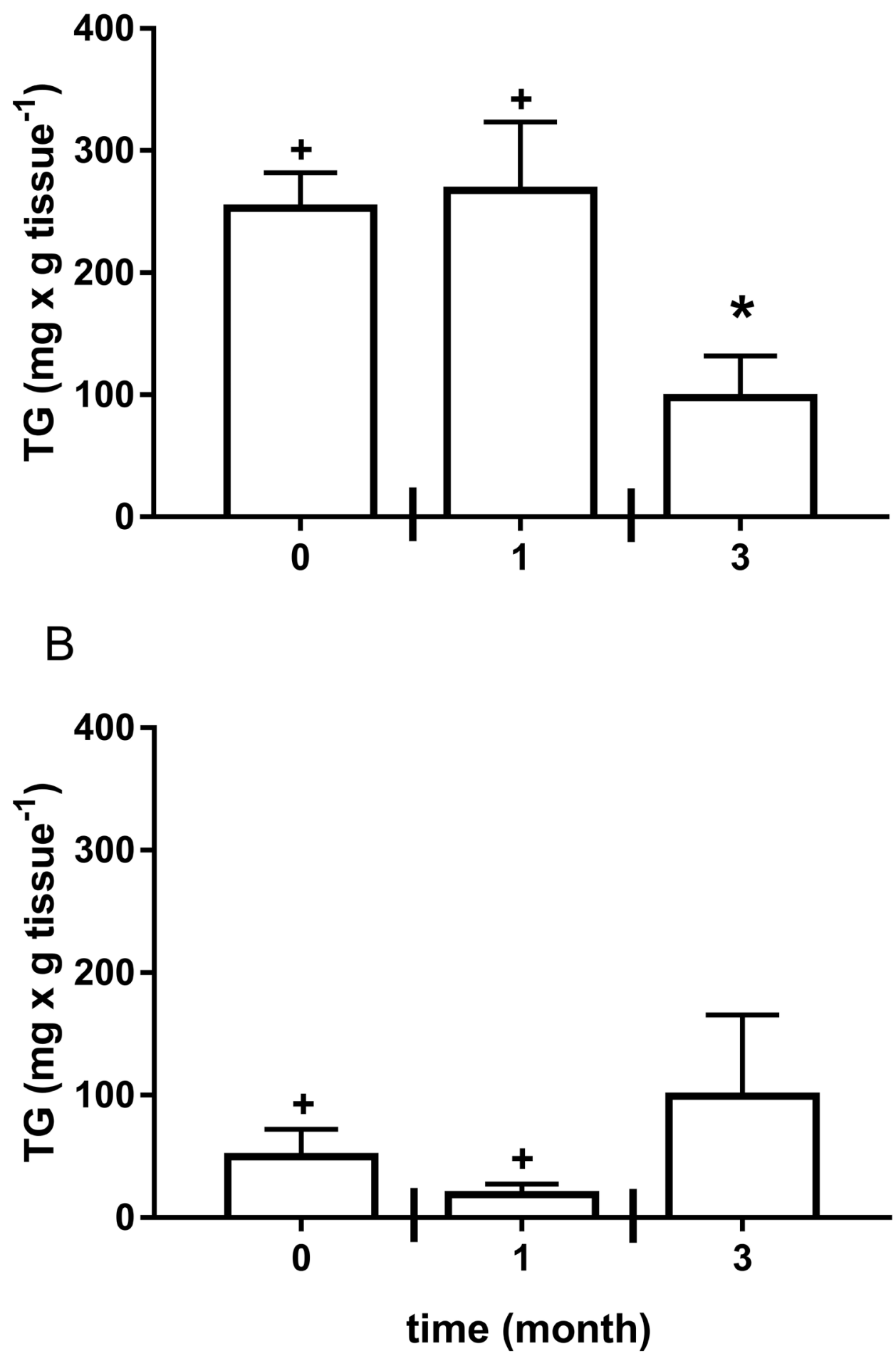

Fig. 2 - Triglyceride (TG) concentration in the hepatopancreas of $N$. granulata from the mudflat (A) and the saltmarsh (B) immediately after capture $\left(t_{0}\right)$ and at months 1 and 3 with the same experimental diet. * indicates significant differences from the corresponding value at $t_{0}$. (One-way RM ANOVA, $p<0.05$ ). ${ }^{+}$indicates significant differences between crabs from the mudflat and the saltmarsh at $\mathrm{t}_{0}$ and at the same time of exposure under a similar diet (t-test, $\mathrm{p}<0.05)$. Data are the mean of five crabs per treatment. 


\section{Protein concentrations}

In crabs from the mudflat, protein concentrations in the hepatopancreas had not changed by month 1 . At month 3, protein concentrations were significantly higher than the values at $\mathrm{t}_{0}$ (increase of about $140 \% ; \mathrm{F}_{(8,2)}=101.34, \mathrm{t}=23.28, \mathrm{p}<0.001$ ) and at month 1 (increase of about $80 \% ; \mathrm{F}_{(8,2)}=101.34, \mathrm{t}=8.04$; $\mathrm{p}=0.004$ ) (Fig. 3A). Protein concentrations in the hepatopancreas of crabs from the saltmarsh did not change throughout the experimental period (Fig. 3B).

When comparing protein concentrations between crabs from the two habitat types, we only observed a difference at month 1 when protein concentrations were lower (about 20\%) in crabs from the saltmarsh than from the mudflat ( $\mathrm{p}=0.012$ ) (Fig. 3 ) but not at $\mathrm{t}_{0}$ or after 3 months (Fig. 3).

\section{Lipase activity}

At month 1, lipase activity in hepatopancreas of crabs from the mudflat was similar to $t_{0}$ while it had decreased about $45 \%$ by month $3\left(\mathrm{~F}_{(8.2)}=18.59 ; \mathrm{t}=6.33 ; \mathrm{p}=0.01\right)$ (Fig. 4A). A decrease in hepatopancreas lipase activity by month 3 (about $40 \%)$ also occurred in crabs from the saltmarsh $\left(\mathrm{F}_{(8,2)}=6.27 ; \mathrm{t}=7.9\right.$; $\mathrm{p}=0.004)$ (Fig. 4B).

No significant differences in lipase activity were observed at $t_{0}$ and month 1 between crabs from the different habitats while at month 3, lipase activity was significantly higher (about $80 \%$ ) in crabs from the saltmarsh $(\mathrm{p}<0.001)$ (Fig. 4).

\section{Levamisole-sensitive and -insensitive AP activity}

In crabs from the mudflat, levamisole-sensitive AP activity increased (about $4000 \%$ ) from $\mathrm{t}_{0}$ to month $1\left(\mathrm{~F}_{(8,2)}=9.66 ; \mathrm{t}=5.11 ; \mathrm{p}=0.011\right)$. At month 3 , the opposite pattern was observed, namely a significant decrease in levamisole-sensitive AP activity (about 3900\%) as compared to month $1\left(\mathrm{~F}_{(8,2)}=29.66\right.$; $\mathrm{t}=6.17 ; \mathrm{p}=0.005)\left(\right.$ Fig. $5 \mathrm{~A}$ ) reaching values similar to $\mathrm{t}_{0}$. No significant changes in levamisole-sensitive AP occurred in hepatopancreas of crabs from the saltmarsh (Fig. 5C) through time.

Levamisole-sensitive AP activity differed significantly between individuals from the two habitat types only at $\mathrm{t}_{0}$, with higher activities in crabs from the saltmarsh (about $6000 \% ; \mathrm{p}=0.004$; Fig. 5A, C).

In crabs from the mudflat, levamisole-insensitive AP activity in hepatopancreas did not change significantly throughout the experimental period (Fig. 5B). In the hepatopancreas of crabs from the saltmarsh, the levamisole-insensitive AP activity was significantly higher (about $300 \%$ ) at month 3 compared to $\mathrm{t}_{0}\left(\mathrm{~F}_{(10,2)}=26.38 ; \mathrm{t}=5.81, \mathrm{p}=0.006\right.$, ) and to month $1\left(\mathrm{~F}_{(10,2)}=26.38 ; \mathrm{t}=5.54 ; \mathrm{p}=0.008\right)$ (Fig. 5D).

No differences were observed between crabs from the two habitat types at $t_{0}$ or at month 1 while at month 3, the levamisole-insensitive AP activity was significantly higher (about $400 \%$ ) in individuals from the saltmarsh compared to the mudflat $(\mathrm{p}<0.001)$ (Fig. 5B, D).

\section{Behavioral and physical crab parameters under exposure to a similar diet}

Crabs from both habitat types did not exhibit any differences in the feeding behavior throughout the experimental period. No mortality occurred in any group.

The hepatosomatic index (HIS) was similar throughout the entire experimental period in crabs from both habitats, the mudflat and the saltmarsh, without any significant differences (Fig. 6). Also, no significant differences of the HIS were found between crabs from the two habitat types at the same time (Fig. 6). 
A
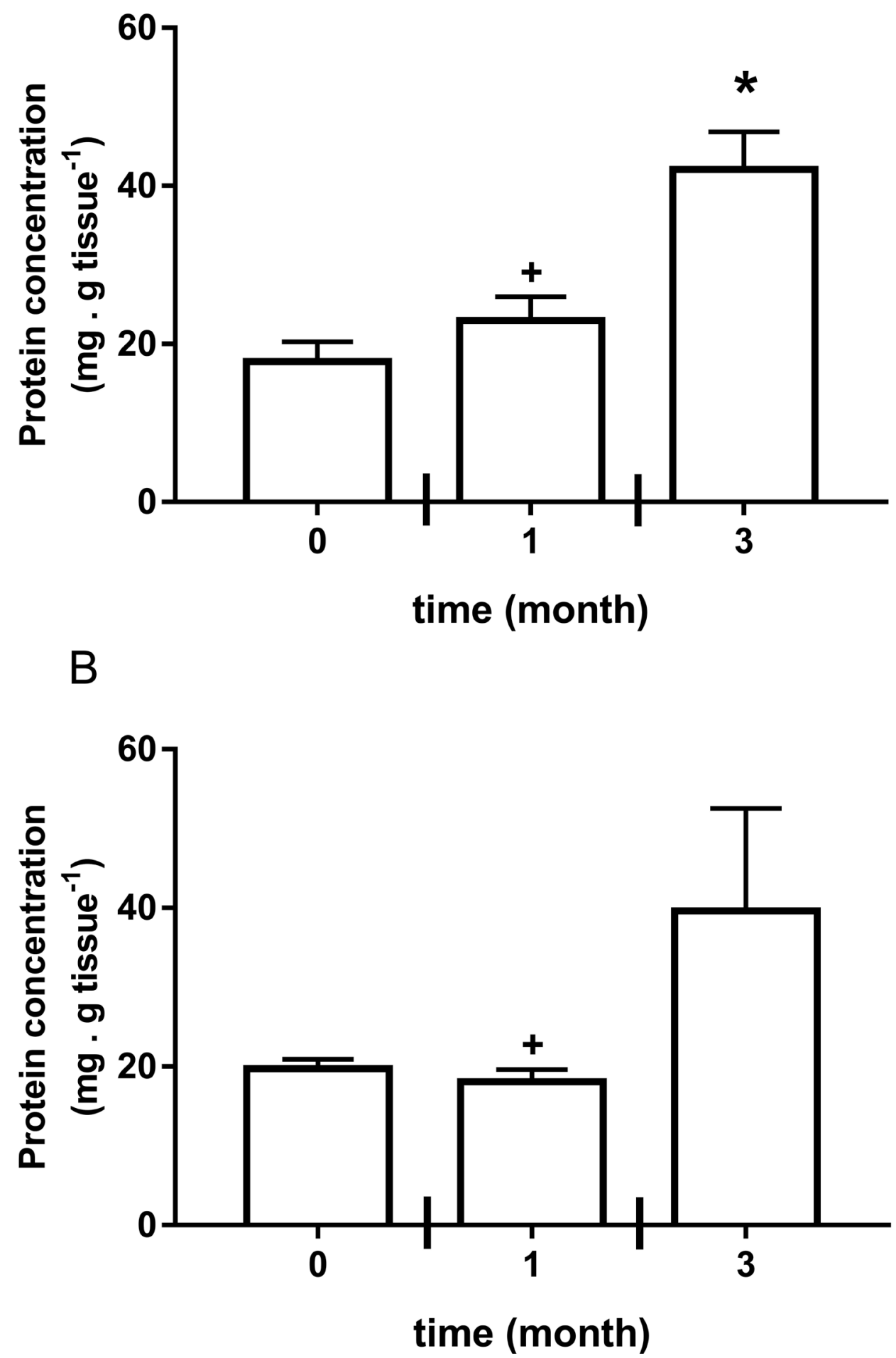

Fig. 3 - Protein concentration in the hepatopancreas of $N$. granulata from the mudflat (A) and the saltmarsh (B) immediately after capture $\left(\mathrm{t}_{0}\right)$ and at month 1 and 3 with the same experimental diet. * indicates significant differences from the corresponding value at $\mathrm{t}_{0}$. (One-way RM ANOVA, $\mathrm{p}<0.05$ ). ${ }^{+}$indicates significant differences between crabs from the mudflat and the saltmarsh at $\mathrm{t}_{0}$ and at the same time of exposure under a similar diet ( $\mathrm{t}$-test, $\mathrm{p}<0.05$ ). Data are the mean of five crabs per treatment. 
A

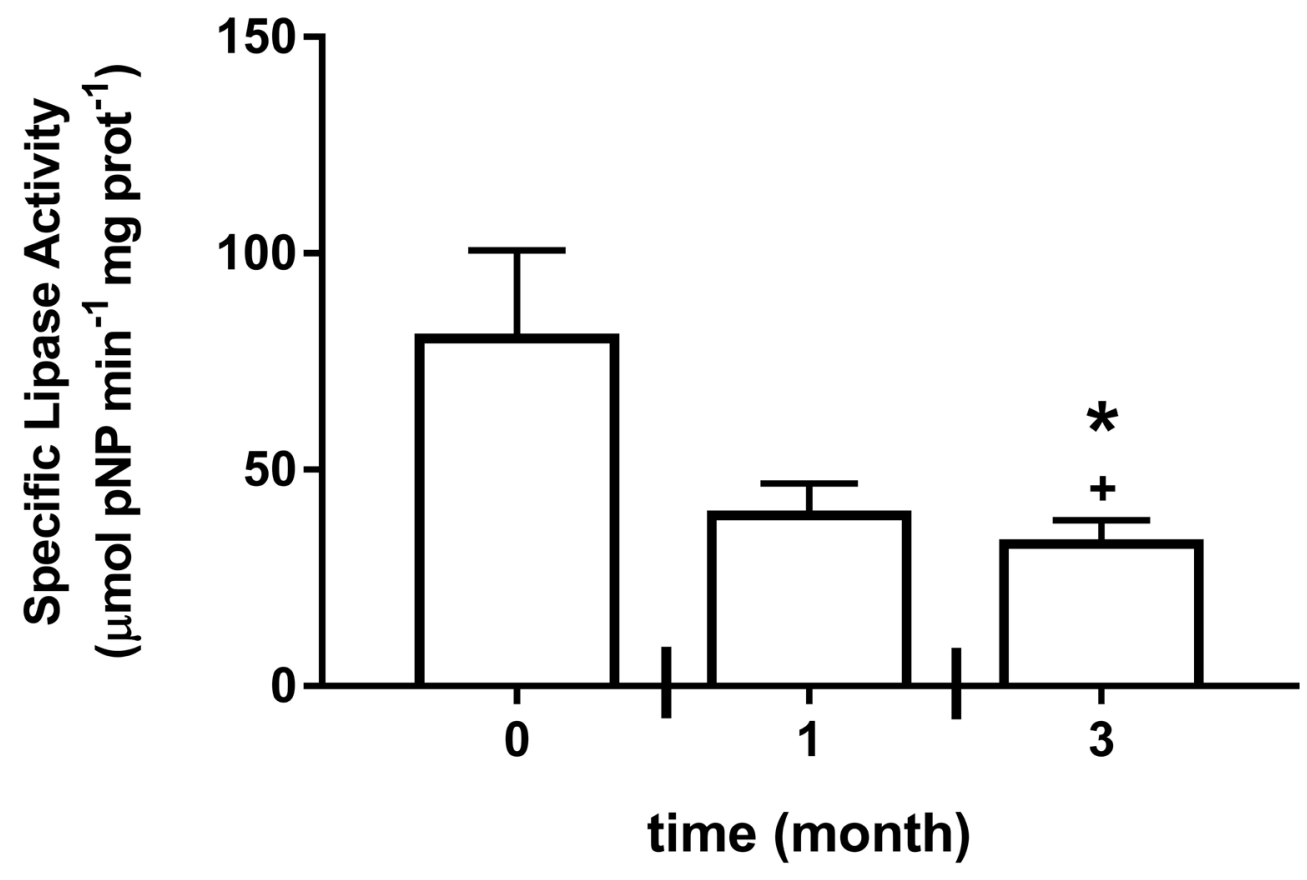

B

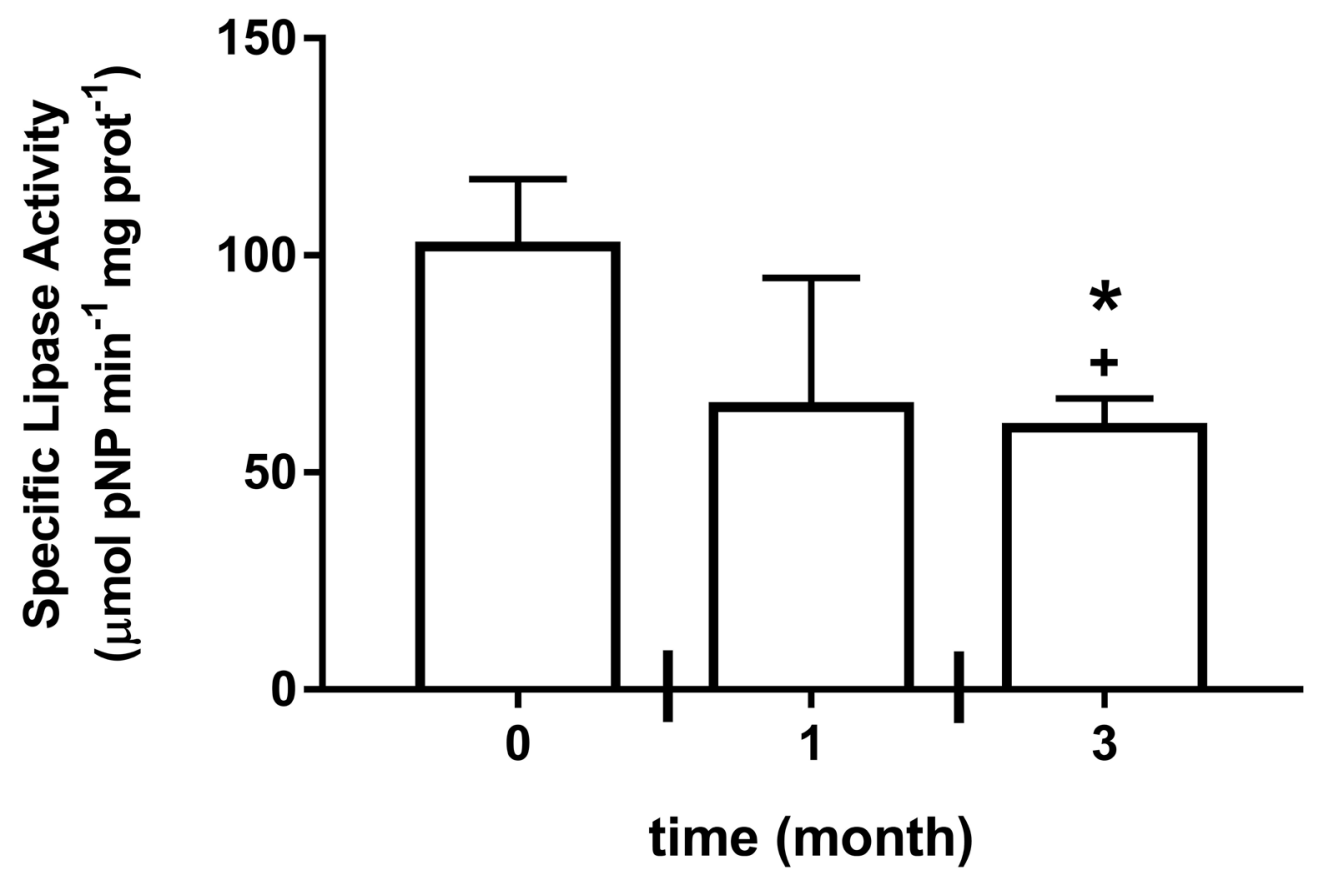

Fig. 4 - Lipase Activity in the hepatopancreas of $N$. granulata from the mudflat (A) and the saltmarsh (B) immediately after capture $\left(\mathrm{t}_{0}\right)$ and at month 1 and 3 with the same experimental diet. * indicates significant differences from the corresponding value at $\mathrm{t}_{0}$. (One-way RM ANOVA, $\mathrm{p}<0.05$ ). ${ }^{+}$indicates significant differences between crabs from the mudflat and the saltmarsh at $t_{0}$ and at the same time of exposure under a similar diet ( $\mathrm{t}$-test, $\mathrm{p}<0.05)$. Data are the mean of five crabs per treatment. 


\section{Discussion}

\section{Lipid metabolism components in the hepatopancreas of $N$. granulata}

\section{Triglyceride concentrations}

Crabs build lipid stores through anabolism mainly by direct uptake of lipids from diet (SABOROWSKI 2015). Digested lipids are mainly stored as triglycerides and in most species, such as N. granulata, the hepatopancreas represents the primary storage site, particularly for long-term energy reserve (PINONI et al. 2011; ŠTRUS et al. 2019; LÓPEZ MAÑANES et al. 2020). In the mudflat of Mar Chiquita Coastal Lagoon, $N$. granulata sustains a diet with high lipid and protein content by consuming mostly animal items (BAS et al. 2014; LANCIA et al. 2014). The higher availability of dietary lipids should be detectable as higher triglyceride concentrations in the hepatopancreas of crabs from the mudflat as compared to saltmarsh in autumn at the time of capture $\left(\mathrm{t}_{0}\right)$, which is indeed the case (Fig. 2). In crabs from the

A

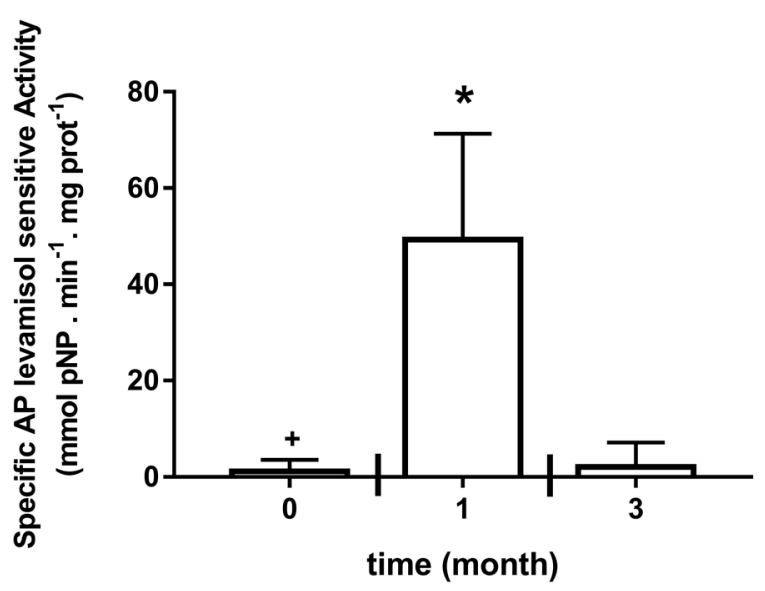

C

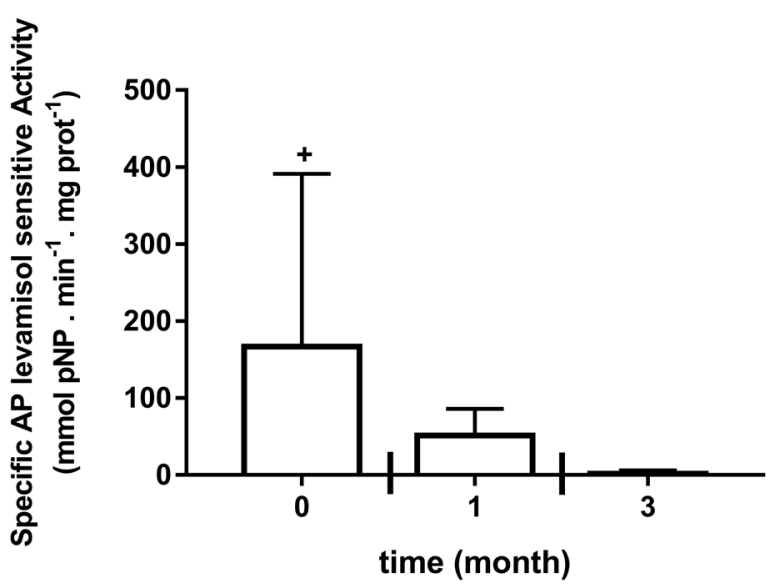

B

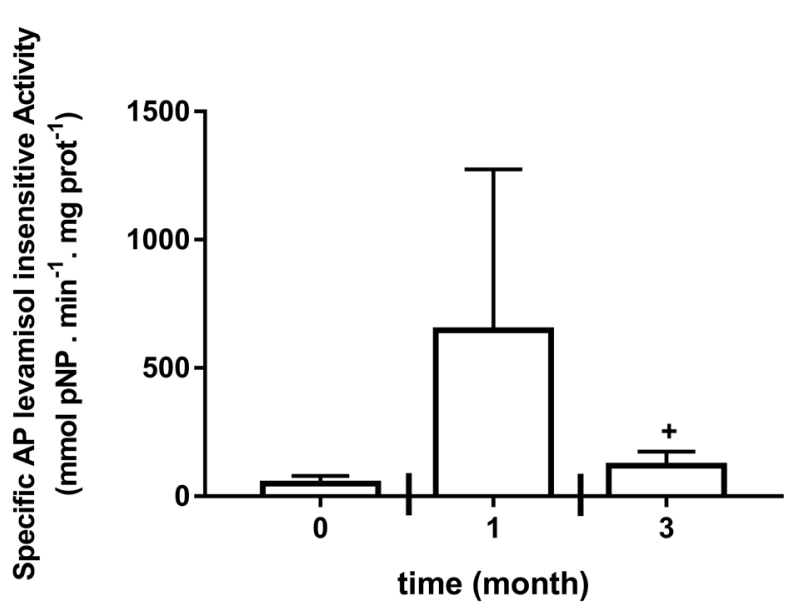

D

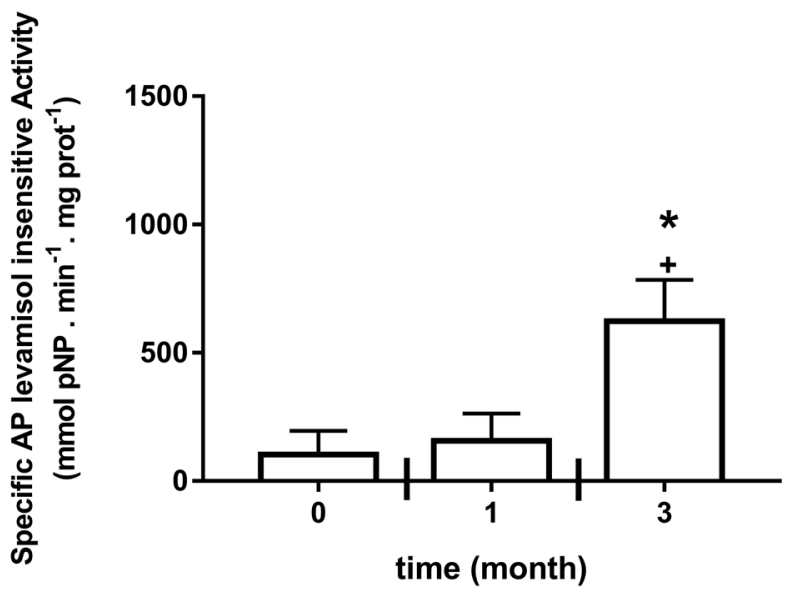

Fig. 5 - Levamisole-sensitive and -insensitive AP activities in the hepatopancreas of $N$. granulata from the mudflat (A-B) and the saltmarsh (C-D), immediately after capture $\left(\mathrm{t}_{0}\right)$ and at month 1 and 3 with the same experimental diet. * indicates significant differences from the corresponding value at $t_{0}$. (Oneway RM ANOVA, $\mathrm{p}<0.05) .{ }^{+}$indicates significant differences between crabs from the mudflat and the saltmarsh at $\mathrm{t}_{0}$ and at the same time of exposure under a similar diet ( $\mathrm{t}$-test, $\mathrm{p}<0.05$ ). Data are the mean for six (mudflat) and five (saltmarsh) crabs per treatment. 
A

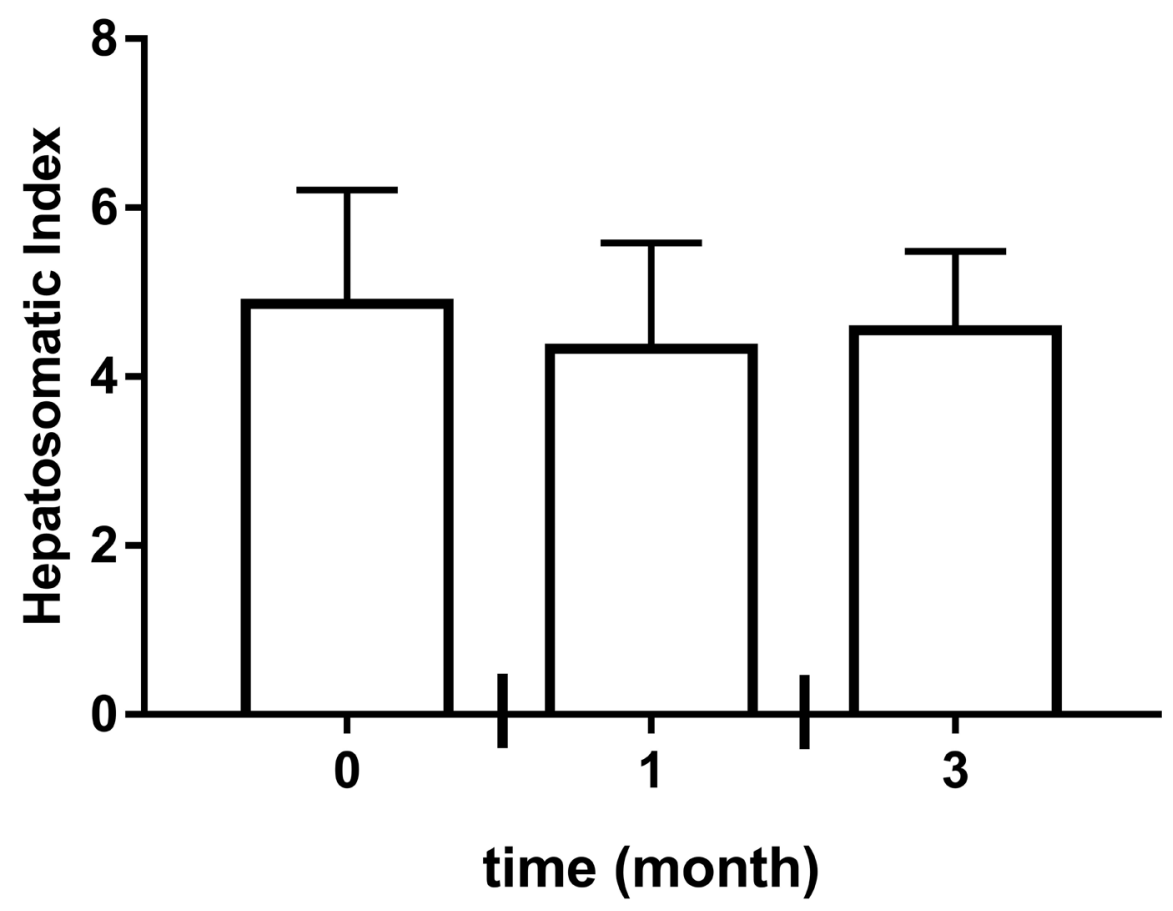

B

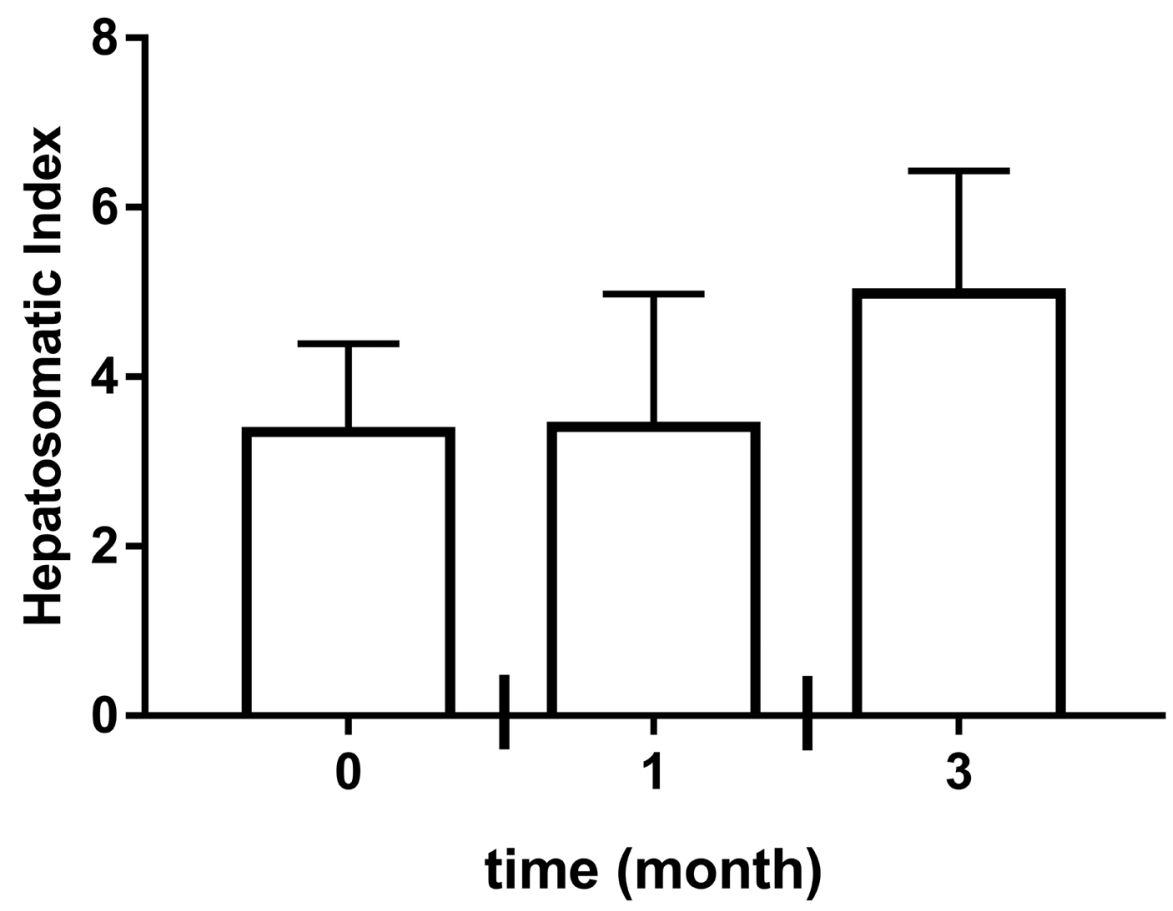

Fig. 6 - Hepatosomatic index of $N$. granulata from the mudflat (A) and the saltmarsh (B) immediately after capture $\left(\mathrm{t}_{0}\right)$ and at month 1 and 3 with the same experimental diet. Data are the mean for six (mudflat) and five (saltmarsh) crabs per treatment. 
mudflat, the significant decrease in triglyceride concentrations at month 3 under an experimental diet of lower lipid content than in the wild (Fig. 2A) supports our hypothesis that the availability of dietary lipids indeed influences the building/degradation of this reserve. Since digestion-absorption routes are still unknown in $N$. granulata, further experiments are needed to establish the link between decreased digestion of dietary lipids and concentration of triglycerides in the hepatopancreas of crabs from the mudflat. In the euryhaline crab Cyrtograpsus angulatus (Dana, 1852), regulation of intracellular lipase activity by external and internal factors is linked to variations in the triglycerides concentrations in the hepatopancreas (MicHIELS et al. 2013).

Adult males from the saltmarsh appeared to be metabolically adapted to the more stable environmental conditions throughout time of this habitat including the kind of available food (LÓPEZ MAÑANES et al. 2020). Digestive and metabolic components of lipid and protein metabolism at the biochemical level in the hepatopancreas appeared to be less sensitive to changes in key environmental factors compared to crabs from the mudflat (PINONI et al. 2013; LÓPEZ MAÑANES et al. 2020). The low consumption of animal dietary items, particularly during autumn, could explain the lower triglycerides content in the hepatopancreas compared to crabs in the mudflat at the time of capture $\left(\mathrm{t}_{0}\right)($ Fig. 2$)$ as we described above. Lipids are limited dietary components for adult males in the saltmarsh (BAS et al. 2014; LANCIA et al. 2014). Crabs in this habitat exhibit digestive and metabolic characteristics suggesting their biochemical adaptation to a diet of low lipids content (LÓPEZ MAÑANES et al. 2020). Our finding that triglyceride concentrations in the hepatopancreas did not change up to month 3 in males from the salt marsh under exposure to an experimental diet with higher proportions of lipids than in the wild, supports this idea (Fig. 2B).

The lack of any statistical difference in hepatopancreas triglyceride concentrations between crabs from the two different habitats sites at 3 months could be attributed to the decrease of this reserve in individuals from the mudflat (Fig. 2).

\section{Lipase activity}

Changes of digestive enzyme activity in the digestive tract can lead to modifications in the digestive capacity for specific nutrients (DEL VALLE \& LÓPEZ MAÑANES 2011, 2012; ROMANO \& ZENG 2012; KARASOV \& DOUGLAS 2013). In various animals, digestive enzyme activity and/or expression changes in direct correlation to the content of specific substrate in the diet (KARASOV \& Douglas 2013). In general, levels of digestive enzymes in the digestive tract of vertebrates correlate positively with those of the corresponding substrate in the diet (MELO et al. 2012; KARASOV \& DOUGLAS 2013). We would also expect this to be the case for lipase activity in hepatopancreas of $N$. granulata from the mudflat since this activity significantly decreased with an experimental diet having lower lipid content that in the wild (Fig. 4A). Furthermore, the simultaneous decrease in both lipase (Fig. 4B) and triglyceride content (Figs 2A, 4A) supports our hypothesis that key components of the lipid metabolism are indeed influenced by diet in crabs from the mudflat.

Some animals exhibit an inverse relationship between levels of digestive enzymes in the digestive tract and specific substrate in the diet, making them an exception to the general hypothesis of a direct relationship as we pointed out above (KARASOV \& DOUGLAS 2013; XIE et al. 2017). This appears to be the case for lipase activity in the hepatopacreas of $N$. granulata from the saltmarsh (Fig. 4), which was lower under a diet with higher lipid content than in the wild.

Our result that between-habitat, intraspecific differences in lipid metabolism indeed occurred with the same experimental diet, is further supported by our findings that in crabs from the saltmarsh, lipase activity was higher at month 3 compared to crabs from the mudflat (Fig. 4), and that modulation of 
MÉNDEZ E. et al., Intraspecific digestive and metabolic variability in an intertidal crab

lipase activity was not linked to variations in triglyceride reserves (Figs 2B, 4B) unlike for crabs from the mudflat.

\section{Protein concentration in the hepatopancreas of $N$. granulata}

In intertidal crabs, protein metabolism plays a key role in biochemical adaptation to various environmental parameters such as variations in diet, salinity and temperature (PINONI et al. 2013, 2018). The hepatopancreas is a site for initial synthesis of macromolecules as for example proteins (ŠTRUS et al. 2019; VogT 2019). The increase in the protein concentration, which we observed (Fig. 3A) at month 3 indicates that diet also affects the protein metabolism of the hepatopancreas of crabs from the mudflat. Whether the increase in protein concentration can compensate for the observed decrease in triglyceride (see above), thereby allowing the maintenance of metabolic and physical conditions (Fig. 6A) requires further investigation.

In the saltmarsh, $N$. granulata are biochemically adapted to a diet with low protein content (LÓPEZ MAÑANES et al. 2020). Under controlled conditions, digestive and metabolic parameters in the hepatopancreas of crabs from the saltmarsh seem to be less affected by variations in key environmental factors such as salinity (PINONI et al. 2013; LÓPEZ MAÑANES et al. 2020). This also appears to be the case for protein concentrations of the hepatopancreas as these did not change throughout the study period with an experimental diet (Fig. 3B), implying that adjustments in protein metabolism (i.e., synthesis/degradation pathways) are most likely not involved in biochemical adaptations of $N$. granulata from the saltmarsh to dietary conditions.

\section{AP activity in the hepatopancreas of $N$. granulata}

In the hepatopancreas of decapod crustaceans, AP are key enzymes due to their role in the synthesis and secretion of digestive enzymes and the absorption of digestive products (e.g., lipids) (VERRI et al. 2001; WANG et al. 2014). Diet-driven changes of levamisole-sensitive AP activity (Fig. 5A) in the hepatopancreas of crabs from the mudflat could possibly be linked to variations in energy reserve content (Figs 2A, 3A). In $N$. granulata, AP activity is involved in postprandial adjustments of protein metabolism in the hepatopancreas (PINONI et al. 2015; PINONI \& LÓPEZ MAÑANES 2016). Postprandial changes in AP and proteolitic activities have been described in $N$. granulata from the mudflat under controlled conditions (PINONI et al. 2015). The simultaneous decrease of levamisole-sensitive AP and lipase activity (Figs 4A, 5A) in the hepatopancreas of crabs from the mudflat suggests a coordinated variation of these activities. A diet with reduced nutrients seemed to lead to lower digestion and absorption of lipids and to a decrease in triglyceride reserves (Fig. 2A). Further studies (e.g., at the cellular level) are needed to establish the possible physiological link between levamisole-sensitive AP and lipase activities in crabs from the mudflat.

Diet appeared to drive levamisole-insensitive AP activity (Fig. 5D) in hepatopancreas of crabs from the saltmarsh (Fig. 5D). Whether the observed, enhanced levamisole-insensitive AP activity is indeed involved in the maintenance of triglycerides and proteins in crabs from the saltmarsh as could be expected from our results (Figs 2B, 3B), requires further investigation. In the closely related euryhaline crab C. angulatus, levamisole-insensitive AP activity has a role in dietary adjustments (PINONI \& LÓPEZ MAÑANES 2016).

In various decapod crustaceans, AP has been involved in macromolecule synthesis (e.g., lipids and proteins) taking place in the hepatopancreas after feeding (MCGAW \& CURTIS 2013; CARTER \& MENTE 2014; WANG et al. 2014; SUN et al. 2021). When energy reserves must be changed in hepatopancreatic 
cells, levamisole-insensitive AP activity appears to be regulated intracellularly in a coordinated fashion to the changes of these reserves (LÓPEZ MAÑANES et al. 2020).

\section{Conclusions}

The different responses of energy reserves and key enzymes to a similar experimental diet in the hepatopancreas of $N$. granulata from the mudflat and saltmarsh illustrate that the specific influence of diet is depending on the habitat of origin.

In the wild, differential adjustments in lipid and protein metabolism (at the level of key digestive enzymes activities and utilization of energy reserves) occur in crabs from the mudflat and the saltmarsh (PINONI et al. 2011; LÓPEZ MAÑANES et al. 2020). Distinct and specific intrinsic mechanisms of regulation (e.g., chemical messengers) could be operating being triggered by the particular environmental characteristics of each site (e.g., food resources). We found that energy reserves and enzyme activities, which are regulated in relation to habitat in the wild, are also differentially affected in crabs from two different habitats during exposure to a similar experimental diet. Our results suggest that these distinct intrinsic mechanisms could continue to be operating during our experiment of three months, leading to a differential use of digestive and metabolic pathways in crabs depending on their habitat of origin.

\section{Financial Support}

This work was partially supported by grants from the University of Mar del Plata (EXA892/18 15/ E850; EXA992/20 15/E950) and from Consejo Nacional de Investigaciones Científicas y Tecnológicas (CONICET), Argentina (PIP N ${ }^{\circ} 112201301$ 00009). E.M. was supported by scholarships from CONICET.

\section{Ethics}

This project was performed following the regulations and statements of Ethics Committee CICUAL (OCA 1499/12), FCEyN Universidad Nacional de Mar del Plata.

\section{References}

AlBANESI C., GONZÁLEZ-CASTROM. \& LÓPEZ-MAÑANESA. (2020). Understanding the early ontogenetic stages of Mugil liza (Mugilidae): Morphological traits and digestive/metabolic profile of pre-juveniles after recruitment. Journal of Fish Biology 98 (3): 643-654. https://doi.org/10.1111/jfb.14605

Angeletti S. \& Cervellini P.M. (2015). Population structure of the burrowing crab Neohelice granulata (Brachyura, Varunidae) in a SW Atlantic salt marsh. Latin American Journal of Aquatic Research 43: 539-547.

Bas C., Lancia J.P., Luppi T., Méndez-Csariego A., Kittlein M. \& SpivaK E. (2014). Influence of tidal regime, diurnal phase, habitat and season on feeding of an intertidal crab. Marine Ecology 35: 319-331. https://doi.org/10.1111/maec.12083

BELGRAD B.A. \& GRIFFEN B.D. (2016). The influence of diet composition on fitness of the blue crab, Callinectes sapidus. PloS ONE 11: e0145481. https://doi.org/10.1371/journal.pone.0145481

BRADFORD M.M. (1976). A rapid and sensitive metod for the quantitation of microgram quantities of protein-dyebinding.AnalyticalBiochemistry72:248-254.https://doi.org/10.1016/0003-2697(76)90527-3 
MÉNDEZ E. et al., Intraspecific digestive and metabolic variability in an intertidal crab

CARTer C. \& Mente E. (2014). Protein synthesis in crustaceans: a review focused on feeding and nutrition. Open Life Sciences 9 (1): 1-10. https://doi.org/10.2478/s11535-013-0134-0

CHAN J.R. \& STINSON R.A. (1986). Dephosphorylation of phosphoproteins of human liver plasma membranes by endogenous and purified liver alkaline phosphatases. Journal of Biological Chemistry 261: 7635-7639.

DA Silva Vianna B., Miyai C.A., Augusto A. \& Costa T.M. (2020). Effects of temperature increase on the physiology and behavior of fiddler crabs. Physiology \& Behavior 215: 112765. https://doi.org/10.1016/j.physbeh.2019.112765

Del VAlle J.C. \& LóPez MaÑanes A.A. (2011). Digestive flexibility in females of the subterranean rodent Ctenomys talarum in their natural habitat. Journal of Experimental Zoology 315A: 141-148. https://doi.org/10.1002/jez.658

Del VAlle J.C. \& LóPez MAÑAnes A.A. (2012). Fisiología integrativa y adaptativa de roedores subterráneos Ctenomys talarum: Modelo de estudio de cambios plásticos frente a variaciones del ambiente y de demanda energética. Editorial Académica Española. LAP Lambert Academic Publishing $\mathrm{GmbH} \& \mathrm{Co}$.

Díez-Zaera M., DíAZ-HernándeZ J.I., HernándeZ-Álvarez E., Zimmermann H., DíazHERNÁNDEZ M. \& MiRAS-PORTUGAL M.T. (2011). Tissue-nonspecific alkaline phosphatase promotes axonal growth of hippocampal neurons. Molecular Biology of the Cell 22: 1014-1024. https://doi.org/10.1091/mbc.e10-09-0740

KARASOv H.W. \& Douglas A.E. (2013). Comparative digestive physiology. Comprehensive Physiology 3: 741-783. https://doi.org/10.1002/cphy.c110054

LALLÈS J.P. (2019). Recent advances in intestinal alkaline phosphatase, inflammation, and nutrition. Nutrition Reviews 77 (10): 710-724. https://doi.org/10.1093/nutrit/nuz015

LANCIA J.P., BAS C. \& SPIVAK E. (2014). Food manipulation and selection in the omnivorous grapsoid crab Neohelice granulata (Decapoda: Varunidae). Scientia Marina 78: 529-536. https://doi.org/10.3989/scimar.04036.02B

Leão T., Siqueira M., Marcondes S., Franco-Belussi L., De Oliveira C. \& Fernandes, C.E. (2021). Comparative liver morphology associated with the hepatosomatic index in five Neotropical anuran species. The Anatomical Record 304 (4): 860-871. https://doi.org/10.1002/ar.24540

Ljungström M., Norberg L., Olaisson H., Wernstedt C., Vega F.V., Arvidson G. \& MÅrdh S. (1984). Characterization of proton-transporting membranes from resting pig gastric mucosa. Biochimica et Biophysica Acta 769: 209-219. https://doi.org/10.1016/0005-2736(84)90025-7

Lopez Mañanes A.A., Asaro A., Méndez E., Michiels M.S. \& Pinoni S.A. (2020). Digestive flexibility in Neohelice granulata from the Mar Chiquita Coastal Lagoon: characterization and modulation of key enzymes in hepatopancreas. In: RodRÍGUEZ E.M. \& LuPPI T.A. (eds) Neohelice granulata, a Model Species for Studies on Crustaceans. Volume II: Anatomy and Physiology: 255-274. Cambridge Scholars Publishing.

Luppi T., Bas C., Méndez Casariego A., Albano M., Lancia J., Kittlein M., Rosenthal A., FARÍAS N., SPIVAK E. \& IRIBARNE O. (2013). The influence of habitat, season and tidal regime in the activity of the intertidal crab Neohelice (= Chasmagnathus) granulata. Helgoland Marine Research 67: 1-15. https://doi.org/10.1007/s10152-012-0300-9

MARKWEG H., LANG M.S. \& WAGNER F. (1995). Dodecanoic acid inhibition of lipase from Acetinobacter sp. OPA 55. Enzyme and Microbial Technology 17: 512-516.

https://doi.org/10.1016/0141-0229(94)00067-2 
MCGAW I.J. \& CURTIS D.L. (2013). A review of gastric processing in decapod crustaceans. Journal of Comparative Physiology B 183 (4): 443-465. https://doi.org/10.1007/s00360-012-0730-3

MELO J.F.B., LundSTEDT L.M., MORAES G. \& INOUE L.A.K.A. (2012). Effect of different concentrations of protein on the digestive system of juvenile silver catfish. Arquivo Brasileiro de Medicina Veterinária e Zootecnia 64: 450-457. https://doi.org/10.1590/S0102-09352012000200027

MÉNDeZ E., LóPez Mañanes A.A. \& PinONi S.A. (2019). Feeding and osmoregulation in the euryhaline crab Neohelice granulata: digestive parameter responses. Animal Biology 69: 433-449. https://doi.org/10.1163/15707563-20191037

Michiels M.S., Del VAlle J.C. \& LóPez MaÑANes A.A. (2013). Effect of environmental salinity and dopamine injections on key digestive enzymes in hepatopancreas of the euryhaline crab Cyrtograsus angulatus (Decapoda: Brachyura: Varunidae). Scientia Marina 77: 129-136. https://doi.org/10.3989/scimar.03687.09D

Michiels M.S., DEL VALLE J.C. \& LÓPEZ MAÑANES A.A. (2015a). Lipase activity sensitive to dopamine, glucagon and cyclic AMP in hepatopancreas of the euryhaline burrowing crab Neohelice granulata. Crustaceana 88: 51-65. https://doi.org/10.1163/15685403-00003399

Michiels M.S., Del Valle J.C. \& LóPez MaÑanes A.A. (2015b). Biochemical characteristics and modulation by external and internal factors of aminopeptidase- $\mathrm{N}$ activity in the hepatopancreas of a euryhaline burrowing crab. Journal of Comparative Physiology B 185: 501-510. https://doi.org/10.1007/s00360-015-0899-3

Michiels M.S., Del Valle J.C. \& LóPez Mañanes A.A. (2017). Trypsin and N-aminopeptidase (APN) activities in the hepatopancreas of an intertidal euryhaline crab: Biochemical characteristics and differential modulation by histamine and salinity. Comparative Biochemistry and Physiology Part A 204: 228-235. https://doi.org/10.1016/j.cbpa.2016.12.003

Michiels M.S., DAleo G.R. \& LóPez MAÑAnes A.A. (2020). Differential modulation after feeding in different salinities and response to abscisic acid (ABA) and extracellular $\mathrm{Ca}^{2+}$ of aminopeptidase $\mathrm{N}$ (APN) activity in the hepatopancreas of the intertidal euryhaline crab Neohelice granulata. Canadian Journal of Zoology 98: 262-268. https://doi.org/10.1139/cjz-2019-0163

Mota A., Silva P., Neves D., Lemos C., Calhau C., Torres D., Martel F., Fraga H., Ribeiro L., Alçada M.N.M.P., Pinho M.J., Negrão M.R., Pedrosa R., Guerreiro S., Guimarães J.T., AZEVEDO I. \& MARTINS M.J. (2008). Characterization of rat heart alkaline phosphatase isoenzymes and modulation of activity. Brazilian Journal of Medical and Biological Research 41: 600-609. https://doi.org/10.1590/S0100-879X2008000700009

MuelLeR S.N. (2017). Grand challenges in immunological memory. Frontiers in Immunology 8: 385. https://doi.org/10.3389/fimmu.2017.00385

NuÑEZ J., RiBEIRO P. \& LUPPI T. (2020). Biogeography and habitat use. In: LUPPI T.A. \& RodRíguEZ E.M (eds) Neohelice granulata, a Model Species for Studies on Crustaceans. Volume I, Life History and Ecology: 291-318. Cambridge Scholars Publishing.

PINONI S.A. (2009). Maintenance Mechanisms of the Internal Medium in Response to Environmental Stress in Decapod Crustaceans of Regional Interest Ph.D. Thesis, Universidad Nacional de Mar del Plata, Mar del Plata, Argentina.

PINONI S.A. \& LÓPEZ MAÑANES A.A. (2008). Partial characterization and response under hyperregulating conditions of $\mathrm{Na}^{+} / \mathrm{K}^{+}$-ATPase and levamisole-sensitive alkaline phosphatase activities in chela muscle of the euryhaline crab Cyrtograpsus angulatus. Scientia Marina 72: 15-24. https://doi.org/10.3989/scimar.2008.72n115 
MÉNDEZ E. et al., Intraspecific digestive and metabolic variability in an intertidal crab

PINONI S.A. \& LóPEZ MAÑANES A.A. (2016). Digestive flexibility in the euryhaline crab Cyrtograpsus angulatus (Decapoda, Brachyura, Varunidae) from Mar Chiquita coastal lagoon (Buenos Aires, Argentina): responses to salinity of key enzymes in hepatopancreas. Pan-American Journal of Aquatic Sciences 11: 345-355.

Pinoni S.A., Goldemberg A.L. \& LóPez MañAnes A.A. (2005). Alkaline phosphatase activities in muscle of the euryhaline crab Chasmagnathus granulatus: response to environmental salinity. Journal of Experimental Marine Biology and Ecology 326: 217-226. https://doi.org/10.1016/j.jembe.2005.06.004

PINONI S.A., IRIBARNE O. \& LÓPEZ MAÑANES A.A. (2011). Between-habitat comparison of digestive enzymes activities and energy reserves in the SW Atlantic euryhaline burrowing crab Neohelice granulata. Comparative Biochemistry and Physiology Part A 158 (4): 552-559. https://doi.org/10.1016/j.cbpa.2010.12.020

Pinoni S.A., Michiels M.S. \& LóPez Mañanes A.A. (2013). Phenotypic flexibility in response to environmental salinity in the euryhaline crab Neohelice granulata from the mudflat and the saltmarsh of a SW coastal lagoon. Marine Biology 160: 2647-2661. https://doi.org/10.1007/s00227-013-2258-9

PinONi S.A., MÉNDEZ E. \& LÓPEZ MAÑANES A.A. (2015). Digestive flexibility in a euryhaline crab from a SW Atlantic coastal lagoon: alkaline phosphatase activity sensitive to salinity in the hepatopancreas. Journal of the Marine Biological Association of the United Kingdom 95: 1133-1140. https://doi.org/10.1017/S0025315415000570

Pinoni S.A., JeRez-CePA I., LóPeZ MaÑAnes A.A. \& MANCERA Romero J.M. (2018). The euryhaline crab Uca tangeri showed metabolic differences to sex and environmental salinity. Journal of the Marine Biological Association of the United Kingdom 98: 1465-1475. https://doi.org/10.1017/S0025315417000601

ROMANO N. \& ZENG C. (2012). Osmoregulation in decapod crustaceans: implications to aquaculture productivity, methods for potential improvement and interactions with elevated ammonia exposure. Aquaculture 334: 12-23. https://doi.org/10.1016/j.aquaculture.2011.12.035

SABOROwski R. (2015). Nutrition and digestion. In: CHANG E.S. \& THIEL M. (eds) The Natural History of the Crustacea. Physiology 4: 285-319. Oxford University Press, New York.

SPIVAK E. (2020). The Southwestern Atlantic intertidal crab Neohelice granulata: history of a successful animal model for scientific research, from XIX century naturalists to XXI century laboratories. In: LuPPI T.A. \& RodríGUEZ E.M. (eds) Neohelice granulata, a Model Species for Studies on Crustaceans. Volume I, Life History and Ecology: 5-22. Cambridge Scholars Publishing.

Štrus J., ŽNidARŠIČ N., MraK P., Bogataj U. \& Vogt G. (2019). Structure, function and development of the digestive system in malacostracan crustaceans and adaptation to different lifestyles. Cell and Tissue Research 377: 415-443. https://doi.org/10.1007/s00441-019-03056-0

SUN S., WANG N. \& ZHU M. (2021). Salinity acclimation alters acid and alkaline phosphatase expression and histological changes in the hepatopancreas of the oriental river prawn Macrobrachium nipponense (De Haan, 1849) (Decapoda: Caridea: Palaemonidae). The Journal of Crustacean Biology 41 (1): ruaa087. https://doi.org/10.1093/jcbiol/ruaa087

Verri T., Mandal A., Zilli L., Bossa D., Mandal P.K., Ingrosso L., Zonno V., Viella S., Aheam G.A. \& STORELLI C. (2001). D-Glucose transport in decapod crustacean hepatopancreas. Comparative Biochemistry and Physiology. Part A 130: 585-606. https://doi.org/10.1016/S1095-6433(01)00434-2

VOGT G. (2019). Functional cytology of the hepatopancreas of decapod crustaceans. Journal of morphology 280: 1405-1444. https://doi.org/10.1002/jmor.21040 
Wang Z.J., Lee J., Sia Y.X., Wanga W., YAng J.M., Yina S.J., Qiana G.Y. \& PARK Y.D. (2014). A folding study of Antarctic krill (Euphausia superba) alkaline phosphatase using denaturants. International Journal of Biological Macromolecules 70: 266-274.

https://doi.org/10.1016/j.ijbiomac.2014.07.001

Xie D., Yang L., Yu R., Chen F., Lu R., QIN C. \& Nie G. (2017). Effects of dietary carbohydrate and lipid levels on growth and hepatic lipid deposition of juvenile tilapia, Oreochromis niloticus. Aquaculture, 479: 696-703. https://doi.org/10.1016/j.aquaculture.2017.07.013

ZAR J.H. (1999). Biostatistical Analysis. Prentice Hall, Upper Saddle River, New Jersey.

Manuscript received: 5 November 2020

Manuscript accepted: 31 August 2021

Published on: 13 September 2021

Branch editor: Marleen De Troch 